UDC 331.461.2:616-089.168.86(470.57)

DOI: 10.21668/health.risk/2020.2.06.eng

\title{
RISK OF A SUDDEN DEATH AT A WORKPLACE CAUSED BY NON-OCCUPATIONAL DISEASES IN BASHKORTOSTAN
}

\author{
L.K. Karimova ${ }^{1}$, N.A. Muldasheva ${ }^{1}$, A.B. Bakirov ${ }^{1}$, Z.F. Gimaeva ${ }^{1,2}$, L.N. Mavrina ${ }^{1}$ \\ ${ }^{1}$ Ufa Research Institute of Occupational Health and Human Ecology, 94 Stepana Kuvykina Str., Ufa, 450106, \\ Russian Federation \\ ${ }^{2}$ Bashkir State Medical University, 3 Lenina Str., Ufa, 450008, Russian Federation
}

The article deals with a pressing issue in occupational medicine, namely, examining sudden deaths at workplaces caused by non-occupational diseases. It contains statistical data on sudden deaths of workers at their workplaces caused by nonoccupational diseases in different economic entities operating in Bashkortostan; there are data on basic death causes revealed via forensic medical examinations; economic branches are ranked as per levels of risks related to sudden deaths at workplaces.

We detected that 268 people died due to non-occupational diseases at enterprises located in Bashkortostan. Number of people who died due to non-occupational diseases at their workplaces increased from 36 to $42 \%$ out of the whole number of people who died at their workplaces. Most frequently sudden deaths occurred among people aged 56-60, with long work experience and blue-collar occupations. Given that, we can assume that there were adverse factors related to working environment and labor process at their workplaces; those factors could produce certain effects on a body during the whole period of working and could aggravate risks of sudden death.

Hidden cardiovascular pathology or a cardiovascular disease that has not been diagnosed while a worker was still alive is a major etiologic factor of a sudden cardiac death.

Most common diseases that cause sudden deaths and risks groups have been determined, and it calls for the necessity to improve periodical medical examinations involving medical experts with necessary specializations and applying a wider range of diagnostic procedures. We have developed a program aimed at reducing risks of sudden deaths at a workplace caused by non-occupational diseases; the program includes a basic set of preventive activities aimed at preventing or reducing probability of a sudden death at a workplace.

Key words: sudden death, mortality, production, non-occupational diseases, workplace, preventive activities, cardiovascular system, circulatory system diseases, working conditions.

Sudden deaths at a workplace remain a pressing issue all over the world. According to estimates made by the International labor Organization (ILO), approximately 2.3 million men and women annually die due to accidents that happened at their workplace or due to work-related diseases; on average, it amounts to 6,000 thousand people every day $[1,2]$.

As Hans-Horst Konkolevsky, General Secretary of the International Social Security Association (ISSA) stated during the $4^{\text {th }}$ AllRussian Week of Labor Protection (2016), an- nually 2.8 million people die at their workplaces. And only $15 \%$ of all these deaths are caused by industrial accidents whereas most of them result from health disorders [3, 4]. Circulatory system diseases cause the greatest share of sudden deaths at a workplace and it often happens they have not been diagnosed while a worker was still alive [5-9].

First sudden deaths at workplaces were fixed in 1969 in Japan; they were called «karoshi» that meant sudden death at a workplace due to cardiac infarction or a stroke

(C) Karimova L.K., Muldasheva N.A., Bakirov A.B., Gimaeva Z.F., Mavrina L.N., 2020

Liliya K. Karimova - Doctor of Medical Sciences, Professor, Chief researcher at the Occupational Medicine Department (e-mail: iao_karimova@rambler.ru; tel.: +7 (347) 255-57-21; ORCID: https://orcid.org/0000-0002-9859-8260).

Nadezhda A. Muldasheva - Researcher at the Occupational Medicine Department (e-mail: muldasheva51@gmail.com; tel.: +7 (917) 416-44-42; ORCID: https://orcid.org/0000-0002-3518-3519).

Akhat B. Bakirov - Doctor of Medical Sciences, Professor, Bashkortostan Academy of Sciences Academician, Director (e-mail: fbun@uniimtech.ru; tel.: +7 (347) 255-19-57; ORCID: https://orcid.org/0000-0001-6593-2704).

Zul'fiya F. Gimaeva - Candidate of Medical Sciences, Senior researcher, Associate Professor at the Department for Therapy and Occupational Diseases (e-mail: gzf-33@mail.ru; tel.: +7 (927) 312-11-97; ORCID: https://orcid.org/0000-0001-6668-2196).

Liana N. Mavrina - Candidate of Biological Sciences, Senior researcher at the Occupational Medicine Department (e-mail: Liana-1981@mail.ru; tel.: +7 (903) 35-39-307; ORCID: https://orcid.org/0000-0002-0250-2683). 
caused by exhaustion, overwork, and stress [10-15]. It was established that deceased people worked 80 hours more per month that they had to in $90 \%$ cases; in $50 \%$ cases they worked 100 hours more than it was actually required by their working schedule. In relation to that, in 2016 a law was passed in Japan that imposed a limitation on excess working hours (45 hours per month, 360 hours per year) for workers employed by large companies [16].

A correlation between long working hours and cardiovascular diseases was confirmed in multiple research works performed in Europe, Asia, and the USA [17-20].

According to some predictions, in the nearest future a risk of sudden death caused by cardiovascular diseases is going to grow among employable population due to rowing prevalence of such risk factors as labor intensity and intense life tempo [9, 21].

Russian research works devoted to determining frequency and clinical and morphological signs of sudden death mostly focus on workers with hazardous occupations such as motor transport drivers, engine drivers, pilots, sailors, coal miners, etc. [22-27].

The most complete data were obtained from the Russian Independent Trade Union of Coal Miners; according to those data, over a period from 2000 to 2013 approximately 2,000 acute cardiovascular deaths occurred among coal miners and overall number of workers who died at their workplaces was considerable higher than a number of those who perished in methane explosions in a mine; the trend was observed in different years. Cardiac infarction was established to be the most frequent cause of sudden death [28].

Given all that, it seems vital to epidemiologically assess prevalence of sudden death at a workplace due to natural reasons and to determine risk groups with the subsequent development of relevant prevention programs. As the issue is truly urgent, it requires full-scale research on frequency and peculiarities of sudden deaths at workplaces occurring at enterprises operating in various branches [29].

Our research goal was to examine reasons of sudden death at a workplace due to non-communicable diseases that were not work-related (common ones) and to develop a scientifically grounded program aimed at preventing and reducing them; enterprises and organizations operating in Bashkortostan were taken as our examples.

Data and methods. In order to achieve the fixed goals, we examined a database provided by the State Labor Inspection, Bashkortostan Regional Office, collected in 2014-2018.

In order to perform comprehensive analysis of sudden deaths at workplaces, we analyzed each case when a worker died at a workplace due to a common disease and we paid great attention to specific circumstances and causes of deaths obtaining all the necessary data from reports on investigations of accidents.

Sudden deaths at workplaces at specific enterprises were summed up as per economic activities and it allowed us to obtain absolute data on a number of deceased, make up a list of organizations with the greatest number of sudden deaths at workplaces due to common diseases and to generalize data as per the following parameters: economic activity types in absolute figures; legal forms of enterprises; positions held by deceased workers; workers' sex and age; data and time at which an accident occurred (month, day of week, time); working conditions categories according to the specific assessment of working conditions; work and leisure regimes; medical examinations; causes of death (disease).

To determine frequency of worker's sudden death at a workplace at different enterprises, we calculated relative mortality at a workplace due to common diseases as per different types of economic activities performed in Bashkortostan. Deaths were calculated per 1,000 workers taking into account average number of workers employed by one company according to data provided by the Federal state Statistic Service, Regional Office in Bashkortostan.

Mortality at a workplace due to common diseases was calculated as per economic activities according to the Russian Classifier of Economic Activities (RCEA). We applied 
the older version, RCEA029-201, to analyze data collected in 2014-2016, and a new one, RCEA-2 (RCEA0.29-2014), to analyze data collected in 2017-2018. Then all the data were systematized according to the comparison table that allowed comparing old and new codes.

Death causes due to common diseases were classified as per the International Classification of Diseases (ICD-10).

Results and discussion. We established that totally 268 workers died at their workplaces due to common diseases in Bashkortostan over the analyzed period. It is rather alerting that in the analyzed period a share of workers who died at their workplaces due to common diseases grew from 36 to $42 \%$ of the total number of those who died at workplaces.

We analyzed sudden deaths at workplaces due to common diseases as per legal form of enterprises or organizations where such deaths occurred. The analysis revealed that $40 \%$ sudden deaths occurred in limited liability companies (LLC); $29 \%$, state and municipal organizations; $11 \%$, joint-stock companies; $8 \%$, closed corporations; and $6 \%$, public companies.

We calculated mortality due to common diseases per 1,000 workers as per economic activity types and revealed that the first rank place in 2014-2016 belonged to production and distribution of electricity, gas and water (0.11\%), and in 2017-2018, to information and telecommunication $(0.21 \% 0)$.

Over the analyzed period 32 vehicle drivers died when they were performing their work tasks. It is well known that working conditions for drivers involve great psychoemotional strain together with hypodynamia as well as exposure to such occupational factors as vibrations, noise, and contamination of working area air with hazardous substances.

Over the analyzed period 13 tractor, bulldozer, and engine drivers died at their workplaces. These occupations involve exposure to specific occupational factors that are mostly physical in their essence (noise and vibration), as well as forced body postures, hypodynamia, and necessity to work in shifts.
All these data indicate that workers with these occupations run higher risks of sudden death at a workplace.

Having analyzed sudden deaths as per gender, we revealed that men died more frequently than women. Gender-related ratio of sudden deaths at a workplace is shown in Figure 1.

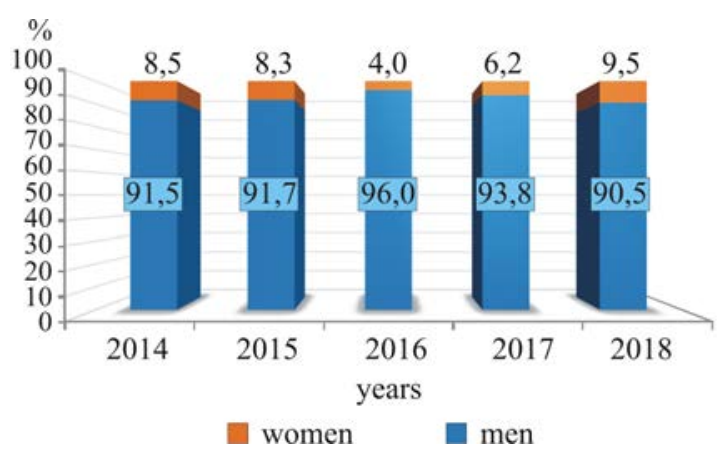

Figure 1. Gender-related ratio of sudden deaths at a workplace due to natural reasons (\%)

We detected a decrease in frequency of sudden deaths due to common diseases depending on age. Both men and women aged 56-60 died most frequently (Figure 2).

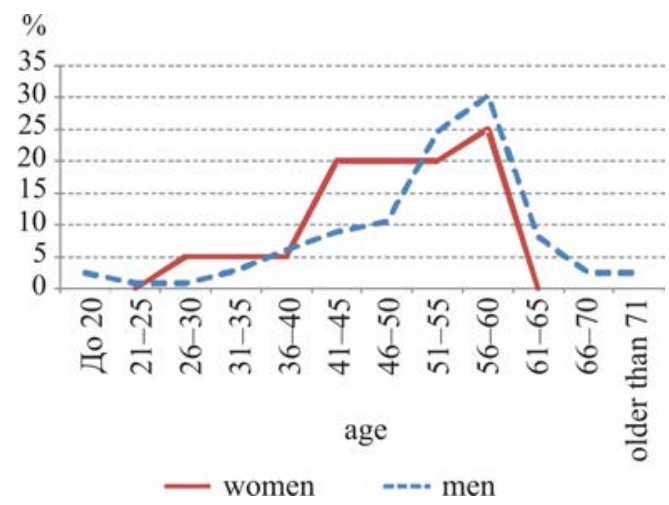

Figure 2. Frequency of sudden deaths due to common diseases among men and women in different age groups $(\%)$

We didn't reveal any authentic discrepancies in number of sudden deaths taken as per months or days of week. As for sudden deaths being distributed as per time of a day, we revealed that the greatest number of sudden deaths occurred in the morning (from 7 a.m. to noon) and in the afternoon (from 1 to 6 p.m.), $44.4 \%$ and $35.8 \%$ accordingly. There were a bit fewer sudden deaths in the evening and at night $(10.8 \%)$. 
We revealed that most deceased workers $(61.6 \%)$ performed their work tasks at workplaces with working conditions category being acceptable as per data obtained via specific assessment of working conditions (SAWC). $22.3 \%$ deceased worked under hazardous conditions; $15.3 \%$, under working conditions belonging to 3.1 hazard category; $6.3 \%, 3.2$ hazard category; $0.7 \%, 3.3$ hazard category; there were no data on working conditions category for $16 \%$ deceased workers (Figure 3).

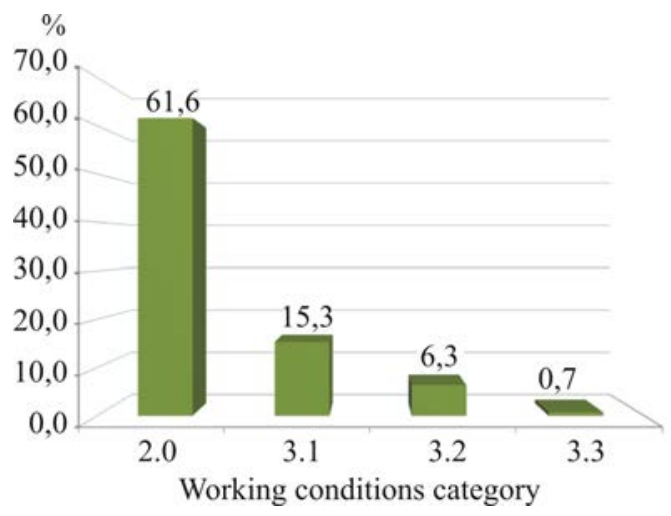

Figure 3. Working condiitons category as per sepcial assessment of working conditions for workers who died at their workplaces due to common diseases (\%)

We should note that workers with long work experience died most frequently, overwhelming majority of them being blue-collar workers $(88 \%)$. Having analyzed forensic reports, we revealed that sudden deaths at workplaces were due to circulatory system diseases $(91.4 \%)$; respiratory organs diseases $(1.9 \%)$; urogenital system diseases $(0.4 \%)$; anaphylactic shock and hypothermia ( 0.8 and $0.45 \%$ accordingly). We can assume that deceased workers had been exposed to adverse occupational factors at their workplaces and the said exposure might have been producing adverse effects on their health and might have become an aggravating risk factor that caused sudden death. Results obtained via investigations of lethal accidents due to common dis- eases allowed establishing that only $19 \%$ deceased workers had undergone an obligatory medical examination prior to being employed, and only $42.2 \%$ had had periodical medical examinations.

According to the Order by the RF Public Healthcare Ministry issued on April 12, 2011 No. 302n, groups of workers that are to have obligatory medical examinations are determined basing on the results of SAWC depending on adverse and/or hazardous occupational factors occurring at workplaces ${ }^{1}$.

But still, it is not likely that data on working class category that existed at workplaces where deceased workers performed their functions are truly authentic. They were obtained via SAWC and it is practically impossible to adequately assess working conditions with this procedure due to certain parameters being groundlessly excluded from it; first of all it comes to parameters that make working conditions more hazardous. Special assessment of working conditions at a given workplace is to be accomplished every five years, except some specific cases. Results obtained via industrial control procedures that are accomplished annually could provide more comprehensive data on variety and levels of exposure to adverse occupational factors; unfortunately, these results are absent in the research data.

Consequently, should working conditions be assigned not so hazardous category as they should be, it results in absence of obligatory medical examinations for workers aimed at determining whether their health corresponds to working tasks they have to perform; absence of timely diagnostics of diseases that can turn out to be medical contraindications for further work that involves exposure to hazardous factors; occupational diseases not being detected at their initial stage.

\footnotetext{
${ }^{1}$ On Approval of the list of adverse and(or) hazardous occupational factors and work tasks that require obligatory preliminary and periodical medical examinations, and of the procedure for accomplishing obligatory preliminary and periodical medical examinations of workers who are employed at workplaces involving hard labor or workplaces with adverse and (or) hazardous working conditions: The Order by the RF Public Healthcare Ministry issued on April 12, 2011 No. 302n (last edited on May 18, 2020). KonsultantPlus. Available at: http://www.consultant.ru/document/cons_doc_LAW_120902/ (19.01.2020) (in Russian).
} 
To obtain authentic data on working class category, it is necessary to harmonize legislation on SAWC and sanitary-hygienic requirements regarding lists of occupational factors and factors related to labor process that are to be examined and measured. Should there be any doubts in quality of performed special assessment of working conditions when an investigation of accident is taking place, we believe it is necessary to submit SAWC results for a state inspection. These data are to be inspected and working conditions are to be reassessed by state experts.

It is also difficult to interpret data due to different approaches to putting up diagnoses used by clinical experts, pathologists, and forensic scientists; sometimes diagnoses from pathologists' reports do not coincide with the International Classification of Diseases (ICD-10).

As we can see form the data given above, circulatory system diseases (CSD) caused sudden death at a workplace in more than $90 \%$ cases. Having looked into it in greater detail, we revealed certain gender-related differences. Thus, men mostly died due to «Other ischemic acute heart diseases» (53.8\%); «Acute myocardial infarction» (11.5\%); «Other forms of chronic ischemic heart diseases» $(10.3 \%)$. Women mostly died due to «Other ischemic acute heart diseases» (47.4\%); «Intracerebral hemorrhage» $(26.3 \%)$; «Cerebral infarction» $(10.4 \%)$.

Consequently, a basic etiologic factor that causes sudden cardiac death is a hidden pathology in the heart and vessels that wasn't diagnosed while a worker was still alive or a cardiovascular system disease that was compensated by the moment of death.

We can assume that people who suffered from cardiovascular system diseases didn't have any medical examinations and therefore were allowed to perform their work tasks under hazardous working conditions.

Determinations of risk groups and most common diseases that cause sudden death calls for improvements in periodical medical examinations with wider participation of medical experts with various specialties and wider range of applied diagnostic procedures.

There are no data in the research on a deceased worker having to work longer hours; whether he or she took annual paid vacations or additional ones during the whole period of work; whether he or she had to perform working tasks under hazardous conditions. It prevented us from establishing any correlations between sudden death at a workplace and exhaustion.

The research gave grounds for creating «The program for reducing risks of death at a workplace due to common diseases»; its main components are sanitary-hygienic, and medical and preventive activities, creating motivation to pursue a healthy lifestyle, and making social and psychological atmosphere within a work team more comfortable for workers.

This program can be an integral part of a consolidated action plan aimed at providing safe working conditions and preserving workers' health, first of all, at enterprises that are considered to be hazardous industrial objects as well as in organizations where sudden deaths at workplaces have been registered.

Special attention should be paid to making medical aid more available for workers via creating and developing services for rendering primary medical aid by aid posts located at industrial objects and settlements for shift workers. These posts should be equipped with all necessary medical devices (electrocardiograph, screening U-sound devices for examining vessels, and defibrillators) and have an ambulance car.

When implemented, the program will allow reducing economic losses and prevent labor losses caused by untimely deaths at workplaces due to common diseases.

\section{Conclusions.}

1. We established that annually in Bashkortostan workers suddenly died at their workplaces due to common diseases (268 registered cases over 2014-2018).

2. Most deceased workers who suddenly died at their workplaces due to common dis- 
eases had been employed by companies operating in such spheres as manufacturing, $23 \%$; transport and logistics, $11.6 \%$; electricity, gas, and steam supply, $10.8 \%$; construction, $10.4 \%$. Overall, more than $60 \%$ sudden deaths occurred in companies operating in these branches of economy.

3 . The highest mortality at workplaces due to common diseases per 1,000 workers was registered for the following economic activities: production and distribution of electricity, gas, and water, $0.1 \%$; mining, $0.11 \%$; construction, $0.084 \%$; information and telecommunications, $0.21 \%$, water supply and sewage, $0.17 \%$; administrative activities, $0.14 \%$; electricity, gas, and steam supply, $0.13 \%$.

4. Men run greater risks of sudden death at a workplace due to common diseases. A share of men among deceased workers varied from $90.5 \%$ to $96 \%$ in different years. Sudden death most frequently occurred among people aged 56-60, both men and women.

5. Circulatory system diseases were the most common reason for sudden death as they accounted for $91.4 \%$ cases. Average age of workers who died due to circulatory system diseases amounted to $51.7 \pm 9.3$. Mortality due to CSD accounted for $91.1 \%$ among men and $95 \%$ among women.

6. Analysis of all the obtained data doesn't allow establishing or disproving any cause-and-effect relations between sudden death at a workplace due to a common diseases and violated requirements to labor safety, exposure to hazardous occupational factors, or improper work and leisure regimes that could influence a deceased worker's health.

7. We scientifically substantiated a set of activities aimed at preventing or reducing risks of sudden death at a workplace due to common diseases; the set includes sanitary-hygienic and medical and preventive measures.

8. In future it is advisable to perform monitoring over parameters of sudden death at a workplace due to a common disease and related economic burden as it will allow assessing its dynamics, economic losses, as well as efficiency of investments into prevention of sudden deaths at workplaces.

Funding. The research was not granted any sponsor support.

Conflict of interests. The authors declare there is no any conflict of interests.

\section{References}

1. Professional'naya patologiya: natsional'noe rukovodstvo [Occupational pathology: a national guide]. In: N.F. Izmerov ed. Moscow, GEOTAR-Media Publ., 2011, 784 p. (in Russian).

2. Bukhtiyarov I.V., Izmerov N.F., Tikhonova G.I., Churanova A.N., Gorchakova T.Yu., Bryleva M.S., Krutko A.A. Work conditions as a risk factor mortality increase in able-bodied population. Meditsina truda i promyshlennaya ekologiya, 2017, no. 8, pp. $43-49$ (in Russian).

3. VNOT Itogi. V Sochi proshla Vserossiiskaya nedelya okhrany truda [RWLP: results. Russian Week of Labor Protection has been held in Sochi]. Getsiz.ru. Available at: https://getsiz.ru/v-sochiproshla-vserossijskaya-nedelya-ohrany-truda.html (14.08.2019) (in Russian).

4. Pyko A.A., Grigorenko E.A., Statkevich T.V., Pyko A.V., Mukalova O.A., Mit'kovskaya N.P. Sudden cardiac death: epidemiological aspects, possibilities of preventive technologies. Kardiologiya $v$ Belarusi, 2016, vol. 8, no. 4, pp. 535-552 (in Russian).

5. Boytsov S.A., Nikulina N.N., Yakushin S.S., Akinina S.A., Furmenko G.I. Sudden cardiac death in patients with coronary heart disease: results of the Russian multi-centre epidemiological Study of mortality, morbidity, and diagnostics and treatment quality in acute CHD. Rossiiskii kardiologicheskii zhurnal, 2011, vol. 16, no. 2, pp. 59-64 (in Russian).

6. Narbut V.V. Smertnost' naseleniya Rossii $v$ trudosposobnom vozraste: gendernye i territorial'nye razlichiya [Mortality among employable population in Russia: gender- and region-related differences]. Vysshee obrazovanie segodnya, 2016, no. 2, pp. 48-51 (in Russian).

7. Priori S.G., Blomstrom-Lundqvist C., Mazzanti A., Blom N., Borggrefe M., Camm J., Elliott P.M., Fitzsimons D. [et al.]. 2015 ESC Guidelines for the management of patients with ventricular arrhythmias 
and the prevention of sudden cardiac death. Eur Heart. J., 2015, vol. 36, no. 41, pp. 2793-2867. DOI: 10.1093/eurheartj/ehv316

8. Babanov S.A., Baraeva R.A. Occupational lesions of the cardiovascular system. Vrach, 2015, no. 3, pp. 7-10 (in Russian).

9. Natsional'nye rekomendatsii po opredeleniyu riska i profilaktike vnezapnoi serdechnoi smerti [National recommendations on determining risks and preventing sudden cardiac death]. The $2^{\text {rd }}$ ed. Moscow, Medpraktika-M Publ., 2018, 247 p. (in Russian).

10. Yang B.F., Shi J.Z., Li Q.J., Xia L.C., Zhang F., Yu Y.G., Xiao N., Li D.R. [et al.]. The Concept, Status Quo and Forensic Pathology of Karoshi. Fa Yi Xue Za Zhi, 2019, vol. 35, no. 4, pp. 455-458. DOI: $10.12116 /$ j.issn.1004-5619.2019.04.015

11. Li J. Karoshi: An international work-related hazard? Int. J. Cardiol., 2016, vol. 1, no. 206, pp. 139-140. DOI: 10.1016/j.ijcard.2016.01.092

12. Xiao N., Yang B.F., Shi J.Z., Yu Y.G., Zhang F., Miao Q., Li D.R. Karoshi May Be a Consequence of Overwork-Related Malignant Arrhythmia. Med Sci Monit, 2019, vol. 12, no. 25, pp. 357-364. DOI: 10.12659/MSM.911685

13. Nishiyama K., Johnson J.V. Karoshi-death from overwork: occupational health consequences of Japanese production management. Int J Health Serv, 1997, vol. 27, no. 4, pp. 625-641. DOI: 10.2190/1JPC-679V-DYNT-HJ6G

14. Wada K., Endo M., Smith D.R. New Reforms to Limit the Excessive Working Hours of Japanese Physicians and Help Prevent Karoshi. J. Occup. Environ. Med., 2019, vol. 61, no. 6, pp. e304-e305. DOI: 10.1097/JOM.0000000000001595

15. Yang Z., Yang B., Li J. Perspectives on compensation and legislation of death due to work overload-karoshi. QJM, 2015, vol. 108, no. 4, pp. 349-350. DOI: 10.1093/qjmed/hcu207

16. Belaya kniga po profilaktike karoshi (smert' ot pereutomleniya) (na yaponskom yazyke) [White book on preventing karoshi (death from overwork) (in Japan)]. Tokio, Ministerstvo zdravookhraneniya, truda i sotsial'nogo obespecheniya Yaponii Publ., 2016. Available at: http://www. mhlw.go.jp/wp/hakusyo/karoushi/16/dl/16-1.pdf (22.02.2019) (in Russian).

17. Hayashi R., Iso H., Yamagishi K., Yatsuya H., Saito I., Kokubo Y., Eshak E.S., Sawada N., Tsugane S. Working Hours and Risk of Acute Myocardial Infarction and Stroke Among Middle-Aged Japanese Men- The Japan Public Health Center-Based Prospective Study Cohort II. Circ J, 2019, vol. 25, no. 83 (5), pp. 1072-1079. DOI: 10.1253/circj.CJ-18-0842

18. Kang M.Y., Park H., Seo J.C., Kim D., Lim Y.H., Lim S., Cho S.H., Hong Y.C. Long working hours and cardiovascular disease: a meta-analysis of epidemiologic studies. J. Occup. Environ. Med., 2012, vol. 54, no. 5, pp. 532-537. DOI: 10.1097/JOM.0b013e31824fe192

19. Kivimäki M., Jokela M., Nyberg S.T., Singh-Manoux A. Long working hours and risk of coronary heart disease and stroke: a systematic review and meta-analysis of published and unpublished data for 603,838 individuals. Lancet, 2015, vol. 31, no. 386 (10005), pp. 1739-1746. DOI: 10.1016/S0140-6736(15)60295-1

20. Lee W., Kang Y.J., Kim T., Choi J., Kang M.Y. The Impact of Working Hours on Cardiovascular Diseases and Moderating Effects of Sex and Type of Work: Results from a Longitudinal Analysis of the Korean Working Population. J. Occup. Environ. Med., 2019, vol. 61, no. 6, pp. e247-e252. DOI: 10.1097/JOM.0000000000001588

21. Bukhtiyarov I.V., Matiukhin V.V., Rubtsov M.Yu. Occupational stress in light of who global plan of action on workers' health implementation Mezhdunarodnyi nauchno-issledovatel'skii zhurnal, 2016, vol. 3, no. 45 (3), pp. 53-55 (in Russian).

22. Tyrenko V.V., Ovchinnikov Yu.V., Bologov S.G., Ignat'ev S.B., Kachnov V.A., Kol'tsov A.V. Problems of prevention of sudden cardiac death in armed forces of the Russian Federation. Izvestiya Rossiiskoi voenno-meditsinskoi akademii, 2017, no. 3, pp. 40-48 (in Russian).

23. Gorokhova S.G., Barkan V.S., Gutor E.M., Lapkina E.E., Muraseeva E.V., Sasonko M.L. Evaluation of ECG screening for diagnosis of acute cardiovascular diseases during preliminary examinations in locomotive crew workers. Meditsina truda i promyshlennaya ekologiya, 2017, no. 7, pp. 21-26 (in Russian).

24. Mirolyubova T.V., Zubarev N.Yu. Smertnost' naseleniya kak indicator zamedleniya sotsial'no-ekonomicheskogo razvitiya regiona [Population mortality as an indicator that socioeconomic 
development in a region slows down]. Ars Administrandi. Iskusstvo upravleniya, 2017, vol. 9, no. 1, pp. 16-31 (in Russian).

25. Zhidkova E.A., Naigovzina N.B., Kalinin M.R., Gutor E.M., Gurevich K.G. The Analysis of the Causes of Sudden Deaths among Workers of Locomotive Crews. Kardiologiya, 2019, vol. 59, no. 6, pp. 42-47 (in Russian).

26. Solovyov V.Yu. A concept of identifying high risk groups of personnel at production facilities with hazardous working conditions. Health Risk Analysis, 2013, no. 3, pp. 27-33 (in Russian). DOI: 10.21668/health.risk/2013.3.03.eng

27. Serebryakov P.V., Melent'ev A.V., Rushkevich O.P. Proizvodstvennye shum i vibratsiya i ikh rol' v regulyatsii serdechnogo ritma [In-plant noise and vibration and their role in heart rate regulation]. Professional'noe zdorov'e i trudovoe dolgoletie: sbornik materialov Mezhdunarodnoi nauchno-prakticheskoi konferentsii. Moscow, Fond nauki i obrazovaniya Publ., 2018, pp. 151-153 (in Russian).

28. Kovaleva N.N. Chastota i kliniko-morfologicheskie proyavleniya vnezapnoi smerti u rabotnikov gorno-khimicheskogo proizvodstva i naseleniya, prozhivayushchego $\mathrm{v}$ zone ego tekhnogennogo vliyaniya [Frequency and clinical-morphological signs of sudden deaths among workers employed at mining-chemical production and among people living in a zone exposed to its technogenic influence]. Meditsina katastrof, 2004, no. 3-4, pp. 33-36 (in Russian).

29. Boitsov S.A., Pogosova N.V., Bubnova M.G., Drapkina O.M., Gavrilova N.E., Eganyan R.A., Kalinina A.M., Karamnova N.S. [et al.]. Cardiovascular prevention 2017. National guidelines. Rossiiskii kardiologicheskii zhurnal, 2018, vol. 23, no. 6, pp. 7-122 (in Russian).

Karimova L.K., Muldasheva N.A., Bakirov A.B., Gimaeva Z.F., Mavrina L.N. Risk of a sudden death at a workplace caused by non-occupational diseases in Bashkortostan. Health Risk Analysis, 2020, no. 2, pp. 55-62. DOI: 10.21668/health.risk/2020.2.06.eng

Received: 19.02 .2020

Accepted: 02.06.2020

Published: 30.06 .2020 